University of Nebraska - Lincoln

DigitalCommons@University of Nebraska - Lincoln

Publications from USDA-ARS / UNL Faculty

U.S. Department of Agriculture: Agricultural

Research Service, Lincoln, Nebraska

2011

Application of BABA and s-ABA for drought resistance in apple

Tom Tworkoski

USDA-ARS, tom.tworkoski@ars.usda.gov

Michael Wisniewski

USDA-ARS, Wisniewski@ars.usda.gov

Timothy Artlip

USDA-ARS, Artlip@ars.usda.gov

Follow this and additional works at: https://digitalcommons.unl.edu/usdaarsfacpub

Tworkoski, Tom; Wisniewski, Michael; and Artlip, Timothy, "Application of BABA and s-ABA for drought resistance in apple" (2011). Publications from USDA-ARS / UNL Faculty. 1128.

https://digitalcommons.unl.edu/usdaarsfacpub/1128

This Article is brought to you for free and open access by the U.S. Department of Agriculture: Agricultural Research Service, Lincoln, Nebraska at DigitalCommons@University of Nebraska - Lincoln. It has been accepted for inclusion in Publications from USDA-ARS / UNL Faculty by an authorized administrator of DigitalCommons@University of Nebraska - Lincoln. 


\title{
Application of BABA and s-ABA for drought resistance in apple
}

\author{
T. Tworkoski*, M. Wisniewski and T. Artlip \\ USDA-ARS, 2217 Wiltshire Road., Appalachian Fruit Research Station, Kearneysville, WV 25430, USA. \\ *E-mail: tom.tworkoski@ars.usda.gov
}

\begin{abstract}
Limited fresh water is a global problem that adversely affects crops, including young apple (Malus $\times$ domestica) trees. Innovative technologies will be needed to ensure tree survival and productivity. Recently, selected chemicals have been used to prepare plants for avoidance and recovery from water stress by a process termed priming. Two priming compounds, abscisic acid (ABA) and DL$\beta$-aminobutyric acid (BABA) have been shown to confer plant protection against a range of biotic and abiotic stresses. Our objective was to determine the resistance to and recovery from dehydration of apple seedlings treated with s-ABA and BABA. Three greenhouse experiments were conducted in which combinations of s-ABA and BABA were applied as a root drench to one-year-old 'Royal Gala' apple trees and responses to dehydration were evaluated. Changes in leaf water potential $\left(\psi_{\mathrm{w}}\right)$, stomatal conductance $\left(\mathrm{g}_{\mathrm{s}}\right)$, transpiration (E), leaf $\mathrm{ABA}$ and growth were measured during dehydration and rehydration. In two experiments, pretreatment with BABA reduced early morning $\mathrm{E}$ but $\mathrm{BABA}$ was not as effective as s-ABA in delaying dehydration-induced wilt of shoot tips. In another experiment during the second week without water both BABA- and s-ABA-treated trees had 42 to $62 \%$ higher leaf $\psi_{\text {w }}$, respectively, and $45 \%$ lower leaf ABA than unwatered controls. Higher leaf $\psi_{w}$ was not consistently associated with reduced $\mathrm{g}_{\mathrm{s}}$ and $\mathrm{E}$ suggesting that mechanisms other than increased stomatal resistance may provide drought resistance. Compared with control trees, there was nearly $80 \%$ more shoot growth following rewatering after dehydration in trees that were primed with BABA and s-ABA (1.0 mM each). Leaf senescence was more evident in s-ABA- than BABA-treated trees and, although growth resumed after dehydration, the amount of growth varied with concentration of the priming treatments. Both individual compounds provided dehydration protection to young apple trees but in combination they were not clearly superior to either compound alone.
\end{abstract}

Key words: Abscisic acid, $\beta$-aminobutyric acid, dehydration, gas exchange, priming, water potential, Malus domestica

\section{Introduction}

Inadequate water is perhaps the most pervasive factor limiting crop production, as it reduces growth, slows phenological development and kills plants (Boyer, 1982; Blum, 1996). Water requirements of young apple (Malus $\times$ domestica) trees are substantial as orchards are increasingly planted at high densities and are managed to provide crops soon after planting. Efficient irrigation can lessen tree water-deficit stress, but fresh water supplies for agriculture are likely to become less abundant in the future (e.g., Land Commodities Report, 2009). Alternative technologies will be needed to help grow trees with reduced or no irrigation. Biological resistance or tolerance to water deficit could be a management tool under reduced water conditions. Trees can acquire dehydration resistance by sensing water deficit and activating defense mechanisms such as reduction of transpiration by stomatal closure, metabolic adjustments such as accumulation of osmolytes, and synthesis of biomolecules suppose to ameliorate dehydration such as dehydrins or other late-embryogenesis-abundant (LEA) proteins (Funkhouser et al., 1994; Artlip and Wisniewski, 2001; Wisniewski et al., 2008).

The plant hormone, abscisic acid (ABA) has long been associated with plant responses to dehydration (Sauter et al., 2001). In apple, ABA in xylem and root increased during the first 3 days of dehydration, but with increased time, $\mathrm{ABA}$ in these components leveled off while ABA in leaves continued to increase (Li et al., 2003). Such increases of ABA can induce closure of stomata as a mechanism to conserve water (Zeevaart and Creelman, 1988).
Application of ABA may also provide avoidance of water deficit by shifting dry weight distribution from shoot to root, possibly by inhibiting shoot growth (Creelman et al., 1990). Applications of ABA can also contribute to primary root elongation accompanied by inhibition of lateral root growth (Guo et al., 2009). Reduced shoot growth and maintenance of root growth would enhance survival under drought conditions (Zhang et al., 2006). Increased growth of the main root axis may enable greater exploitation of soil for water.

Various supplemental chemicals, including plant growth regulators, have been shown to modify plant processes to improve survival and recovery from dehydration (Asare-Boama et al., 1986; Wang and Steffens, 1985). Apple trees that were root drenched with paclobutrazol had smaller reductions of leaf water potential with increased time during dehydration (Zhu et al., 2004). Applications of chitosan to apple leaves have alleviated water-deficit stress and associated oxidative stress (Yang et al., 2009). In lime (Citrus aurantifolia L.), foliar applications of spermidine improved dehydration tolerance by reducing electrolyte leakage (Amri and Shahsavar, 2010).

Dehydration resistance can also be induced indirectly by chemical or physical "priming". Priming can protect plants by exposing them to environmental or chemical treatments that enhance capacity to respond to dehydration by mechanisms that avoid or ameliorate stress (Conrath et al., 2002; 2006). The non-protein compound DL- $\beta$-aminobutyric acid (BABA) has been shown to confer plant protection, against a wide range of biotic and abiotic stresses (Jakab et al., 2005). In their research, priming 
with BABA increased fast reduction of stomatal aperture size in response to dehydration. They concluded that BABA-induced dehydration tolerance was achieved primarily via enhanced ABA accumulation. However, in contrast, BABA priming also increased dehydration tolerance by an ABA-independent pathway that suppressed lignification while increasing cell rigidity in crabapple (Malus pumila) (Macarisin et al., 2009). It is thus possible that ABA-dependent and -independent mechanisms act through BABA priming. Accordingly, we hypothesized that applications of ABA and BABA provide dehydration protection by related but different mechanisms that can improve survival of young apple seedlings exposed to water-deficit stress. Our objective was to determine the resistance to and recovery from dehydration of apple seedlings primed with ABA and BABA individually and in combination.

\section{Materials and methods}

Three greenhouse experiments were conducted in which root drenches of BABA were applied alone or in combination with ABA. Tree response during subsequent dehydration and rehydration was measured to evaluate the chemical priming effect.

Trees: Apple seedlings (Malus x domestica cv. Royal Gala) were propagated in tissue culture at the USDA-ARS-NAAAFRS facility (Kearneysville, WV) as per Norelli et al. (1988) and Ko et al. (2002), at $21^{\circ} \mathrm{C}, 16 \mathrm{~h}$ light, $70 \mu \mathrm{mol}$ photons $\mathrm{m}^{-2} \mathrm{~s}^{-1}$ photosynthetic photon flux density (PPFD), with root induction as per Bolar et al. (1998). Upon root formation, the seedlings were transferred to Oasis rooting cubes (Smithers-Oasis, Kent, $\mathrm{OH}$ ), and maintained in a Conviron TC16 tissue culture chamber (Conviron, Winnipeg, MB, Canada) for one month $\left(24{ }^{\circ} \mathrm{C}, 70 \%\right.$ $\mathrm{RH}, 20 \mathrm{~h}$ light, $70 \mu \mathrm{mol}$ photons $\mathrm{m}^{2} \mathrm{~s}^{-1}$ PPFD), with watering as needed and nutrient solution application weekly. They were then transferred to a glasshouse, where they were transplanted into $8 \mathrm{~L}$ pots with Metromix 310 (Scotts - Sierra Horticultural Products Co., Marysville, $\mathrm{OH}$ ). The trees were grown in a glasshouse with supplemental lighting (400 W HPS lamps) to maintain the day length at 16 hours, and a maximum-minimum temperature range 35 to $20^{\circ} \mathrm{C}$. Trees were watered daily, and re-fertilized weekly; trees were in the glasshouse for a total of 6-12 months, with caliper ranging from $0.5 \mathrm{~cm}$ to slightly more than $1.0 \mathrm{~cm}$, and heights varying from 1 to $2 \mathrm{~m}$.

Experiment 1. Effects of multiple applications of BABA on apple response to dehydration: Three treatments were applied as a root system drench to trees grown in $8 \mathrm{~L}$ pots: daily BABA (Acros Organics, Morris Plains, NJ, USA); alternating daily water with BABA; and water only. One liter of BABA $(0.5 \mathrm{mM})$ or water was applied per pot per irrigation. After 4 months of treatments, water was withheld and trees were measured for early morning and midday stomatal conductance $\left(g_{s}\right)$, transpiration $(E)$, and photosynthesis (A) of three mature leaves per tree (CIRAS1; PP Systems, Haverhill, Mass.) on days 1 and 7 during the drought. On day 7, soil moisture and relative leaf water content were measured:

Soil Moisture Content $(\%)=[($ soil fw - soil dw $) /$ soil dw $]$ x 100 .

Leaf Relative Water Content $(\%)=[($ leaf $\mathrm{fw}-$ leaf $\mathrm{dw}) /($ leaf saturated $w t-l e a f d w)]$ x 100

The experiment was in a completely randomized design with 3 treatments and 5 biological replicates (i.e., 15 trees total).
Experiment 2. Dehydration-induced wilt after one-day pretreatment with BABA and s-ABA: A root drench of 500 $\mathrm{mL}$ of water, 1.0 mM s-ABA (Valent-VBC-30101, Lot No. 78020 -VB with $10 \% \mathrm{~s}-\mathrm{ABA}$ ) or $1.0 \mathrm{mM}$ BABA was applied to apple trees (described above) before withholding irrigation in the greenhouse. For each tree the days without water (DWW) was recorded when wilt was evident (terminal shoot and young leaf droop). After wilt appeared, each tree was rewatered. Trees were then maintained to determine if they survived and whether there was new shoot growth that differed among trees that received different treatments prior to drought. For each treatment the average of DWW until wilt and of 10 shoot lengths (measured 1 month after rewatering following drought) was calculated. The experimental design consisted of a trial in which 10 trees each received one of 3 dehydration / chemical treatments (BABA, s-ABA, and no chemical) and no drought treatment for a total of 4 treatments.

Experiment 3. Response to dehydration after one-day pretreatment with combined applications of BABA and sABA: One-year-old own-rooted 'Royal Gala' apple trees were grown from tissue culture and grown in a greenhouse as described above. Trees were soil drenched once with $0,0.5$ and $1.0 \mathrm{mM}$ BABA in combination with $0,0.5$, and $1.0 \mathrm{mM} \mathrm{s}-\mathrm{ABA}$ over a 1 day period. Drenching included placing trees in pots into individual trays so that after applying the BABA and ABA from the top, the pots stood in the solution for one day before excess solution drained from the pots. Prior to dehydration the tops of pots were covered with plastic to reduce evaporative water loss from soil. Irrigation was then withheld. Trees were rewatered after two weeks of dehydration and new growth was measured after one month.

Three mature leaves from the top, middle, and lower canopy of each tree were measured every 2 days for predawn leaf water potential with a pressure chamber (Soil Moisture Equipment Corp., Santa Barbara, Calif.). Each leaf was covered and cut, and water potential was measured. The three leaves were then pooled, quickly frozen in liquid $\mathrm{N}$, lyophilized and analyzed for abscisic acid (ABA) content. Trees were measured every 2 to 5 days for stomatal conductance. Rate of leaf water potential decrease was used as an index of stress. When wilt was evident (or $-2.5 \mathrm{MPa}$ leaf $\psi_{\mathrm{w}}$ was reached) in non-primed but dehydration-treated trees, watering of all trees resumed.

The experimental design was a $3 \times 3$ factorial ( 9 treatments) with 3 replicates plus 3 well-watered controls (i.e. 30 trees, each tree an experimental unit). Three-leaf subsamples were collected from each tree at 2- to 5-day intervals as dehydration proceeded and on day 17 (3 days after watering resumed).

ABA analysis: Leaf samples (0.2 g) were extracted overnight at $-20^{\circ} \mathrm{C}$ with $80 \%$ methanol (fortified with stable isotope, 3', 5', 5', 7', 7', 7'-d6 ABA, butylhydroxytoluene and ascorbic acid). Samples were centrifuged, decanted, re-extracted and the supernatants were pooled and filtered. The extract was rotary flash evaporated, chilled to $0^{\circ} \mathrm{C}$, decanted, and passed through a column of insoluble polyvinylpyrrilidone. Extracts were adjusted to $\mathrm{pH} 3$, passed through $\mathrm{C} 18$ columns (Varian Bond Elut C18 $200 \mathrm{mg}$ Lake Forest CA 92630), eluted with 80\% methanol (with Rapid Trace SPE, Caliper Life Sciences, Hopkinton, MA 01748), and dried. The extracts were methylated with ethereal 
diazomethane and quantified by gas chromatography-mass spectrometry, correcting for losses with the internal standard. Abscisic acid was analyzed with a gas chromatograph (Thermo Trace GC Ultra) equipped with a $30 \mathrm{~m}$ x $0.320 \mathrm{~mm} \times 0.25$ micron column (DB5, J\&W Scientific) and mass selective detector (DSQ II, Thermo). Chromatographic conditions were injector $\left(250^{\circ} \mathrm{C}\right)$, detector $\left(315^{\circ} \mathrm{C}\right)$, and oven from 60 to $200{ }^{\circ} \mathrm{C}\left(5^{\circ} \mathrm{C} / \mathrm{min}\right), 200$ to $300^{\circ} \mathrm{C}\left(30^{\circ} \mathrm{C} / \mathrm{min}\right)$, hold at $300{ }^{\circ} \mathrm{C}$ for $10 \mathrm{~min}$, then 300 to 60 ${ }^{\circ} \mathrm{C}\left(50{ }^{\circ} \mathrm{C} / \mathrm{min}\right)$. The ABA eluted at $29.6 \mathrm{~min}$ and quantitation was accomplished by monitoring authentic ABA (m/z 190) and d6-ABA (m/z 194) with selective ion monitoring (100 msec dwell per ion). The limit of ABA quantitation was $500 \mathrm{pg}$ and the recovery average was $42 \%$.

\section{Results}

Experiment 1. Effects of multiple applications of BABA on apple response to dehydration: After 7 days without water, the soil moisture and leaf RWC did not differ among treatments. The leaf RWC for trees treated with daily BABA, alternate days BABA, and water alone was $45.9,51.8$ and $47.5 \%$, respectively. Soil moisture was $0.20,0.19$ and $0.22 \%$ for trees receiving daily BABA, alternate days BABA, and water, respectively. However, treatments did affect $g_{s}, E$, and $A$ (Table 1). On the first day after withholding water, BABA-treated trees had lower E than control trees early in the morning but by noon $E$ had decreased and was not different from control trees. After 7 days of dehydration, BABA-treated trees had higher E than control trees. Although leaf RWC was not affected by treatment, whole plant water loss may have been reduced over time by BABA that enabled higher E after 7 days of drought. Root drenches with BABA did not differ in $\mathrm{E}$ or $\mathrm{g}_{\mathrm{s}}$ whether applied every watering or with alternate waterings (Table 1).

Experiment 2. Dehydration-induced wilt after one-day pretreatment with BABA and s-ABA: Only s-ABA delayed the onset of drought symptoms compared to water alone (data not shown). However, 1.0 mM s-ABA caused apple leaf chlorosis and senescence, particularly in leaves of the lower canopy. The average number of days to wilt for trees treated with water, BABA, and s-ABA were 9, 7, and 12 days, respectively. Average growth one month after rewatering was 23 and $29 \mathrm{~cm}$, respectively for water and BABA treatments that were significantly greater than $15 \mathrm{~cm}$ growth for the s-ABA treatment.
Table 2. Leaf water potential $\left(\psi_{w}\right)$ and stomatal conductance $\left(\mathrm{g}_{\mathrm{s}}\right)$ of 'Royal Gala' apple trees after withholding water. Trees had received a one day root drench with $\mathrm{BABA}$ and s-ABA prior to withholding water (day 0 ) and then rewatered (day 17)

\begin{tabular}{|c|c|c|c|c|c|c|}
\hline \multirow[t]{2}{*}{ Treatment } & \multicolumn{6}{|c|}{ Days without water } \\
\hline & 0 & 2 & 7 & 12 & 14 & 17 \\
\hline & \multicolumn{6}{|c|}{$\psi_{\mathrm{w}}(-\mathrm{MPa})$} \\
\hline BABA & 0.51 & 0.49 & 0.57 & $1.20 b^{*}$ & $1.25 \mathrm{~b}$ & 0.76 \\
\hline s-ABA & 0.56 & 0.50 & 0.55 & $0.90 \mathrm{bc}$ & $0.83 \mathrm{bc}$ & 0.70 \\
\hline Not watered & 0.57 & 0.51 & 0.64 & $2.12 \mathrm{a}$ & $2.36 \mathrm{a}$ & 0.72 \\
\hline \multirow[t]{2}{*}{ Watered } & 0.50 & 0.52 & 0.50 & $0.62 \mathrm{c}$ & $0.57 \mathrm{c}$ & 0.75 \\
\hline & \multicolumn{6}{|c|}{$\mathrm{P}>\mathrm{F}$} \\
\hline BABA & 0.54 & 0.86 & 0.57 & 0.03 & 0.04 & 0.08 \\
\hline s-ABA & 0.48 & 0.79 & 0.35 & 0.01 & 0.01 & 0.44 \\
\hline \multirow[t]{2}{*}{ Interaction } & 0.05 & 0.94 & 0.86 & 0.02 & 0.03 & 0.62 \\
\hline & \multicolumn{6}{|c|}{$\mathrm{g}_{\mathrm{s}}\left(\mathrm{mmol} \mathrm{m} \mathrm{m}^{-2} \mathrm{~s}^{-2}\right)$} \\
\hline BABA & 132 & $\mathrm{NM}^{* *}$ & $158 \mathrm{a}$ & 152 & NM & 122 \\
\hline s-ABA & 167 & NM & $90 \mathrm{~b}$ & 135 & NM & 95 \\
\hline Not watered & 187 & NM & $159 \mathrm{a}$ & 109 & NM & 113 \\
\hline \multirow[t]{2}{*}{ Watered } & 192 & NM & $114 \mathrm{ab}$ & 173 & NM & 129 \\
\hline & \multicolumn{6}{|c|}{$\mathrm{P}>\mathrm{F}$} \\
\hline BABA & 0.78 & & 0.54 & 0.20 & & 0.05 \\
\hline s-ABA & 0.61 & & 0.01 & 0.63 & & 0.53 \\
\hline Interaction & 0.86 & & 0.36 & 0.08 & & 0.98 \\
\hline
\end{tabular}

Experiment 3. Response to dehydration after one-day pretreatment with combined applications of BABA and s-ABA on apple: Compared to non-primed trees, trees primed with s-ABA and BABA significantly increased leaf water potential (made leaf $\psi_{\mathrm{w}}$ less negative) after seven days of dehydration (Fig. 1). There also was a significant interaction between s-ABA and BABA during this period. At $0 \mathrm{mM} \mathrm{s}-\mathrm{ABA}$ each of the two BABA rates ameliorated leaf water deficit (Fig. 1. A). BABA however did not further ameliorate leaf water deficit when applied in combination with s-ABA (Fig. 1. B and C). In contrast, s-ABA alone or in combination with either concentration of BABA ameliorated leaf water deficit (Fig. 1. B and C). After re-watering (day 17) all trees had the same leaf $\psi_{\mathrm{w}}$.

On day 7 root-applied s-ABA significantly reduced $g_{s}$ (Table 2) and also reduced $\mathrm{E}$ and $\mathrm{A}$ (data not shown). Tree shoot growth after dehydration significantly increased with a pre-dehydration soil drench of BABA alone but not s-ABA alone (Fig. 2). A significant interaction associated with shoot re-growth was determined when s-ABA and BABA were applied together. When applied alone the $1.0 \mathrm{mM}$ s-ABA significantly reduced shoot regrowth after dehydration and re-watering. Average one-month

Table 1. Transpiration (E), stomatal conductance $\left(\mathrm{g}_{\mathrm{s}}\right.$ ), and photosynthesis (A) of 'Royal Gala' apple trees measured early morning (AM) and at noon (PM) after 1 and 7 days without water. Trees had received daily or alternate watering with BABA for 4 months prior to withholding water

\begin{tabular}{|c|c|c|c|c|c|c|c|}
\hline \multirow[t]{3}{*}{$\overline{\mathrm{MT} *}$} & \multirow[t]{3}{*}{ Treatment (T) } & \multicolumn{3}{|c|}{1 day without water } & \multicolumn{3}{|c|}{7 days without water } \\
\hline & & $\mathrm{E}$ & $\mathrm{g}_{\mathrm{s}}$ & A & $\mathrm{E}$ & $\mathrm{g}_{\mathrm{s}}$ & $\mathrm{A}$ \\
\hline & & \multicolumn{2}{|c|}{$\left(\mathrm{mmol} \mathrm{m} \mathrm{m}^{-2} \mathrm{~s}^{-2}\right)$} & $\left(\mu \mathrm{mol} \mathrm{CO}{ }_{2} \mathrm{~m}^{-2} \mathrm{~s}^{-2}\right)$ & \multicolumn{2}{|c|}{$\left(\mathrm{mmol} \mathrm{m} \mathrm{m}^{-2} \mathrm{~s}^{-2}\right)$} & $\left(\mu \mathrm{mol} \mathrm{CO} \mathrm{m}^{-2} \mathrm{~s}^{-2}\right)$ \\
\hline \multirow[t]{3}{*}{$\overline{\mathrm{AM}}$} & BABA daily & $1.6 b^{*}$ & $99 \mathrm{~b}$ & $7.5 \mathrm{ab}$ & $0.5 \mathrm{a}$ & $36 \mathrm{a}$ & $4.0 \mathrm{a}$ \\
\hline & BABA alternate & $1.7 \mathrm{~b}$ & $93 \mathrm{~b}$ & $6.4 \mathrm{~b}$ & $0.5 \mathrm{a}$ & $33 \mathrm{a}$ & $4.3 \mathrm{a}$ \\
\hline & Water & $2.5 \mathrm{a}$ & $146 \mathrm{a}$ & $9.2 \mathrm{a}$ & $0.2 \mathrm{~b}$ & $15 \mathrm{~b}$ & $0.9 \mathrm{~b}$ \\
\hline \multirow[t]{4}{*}{ PM } & BABA daily & $1.4 \mathrm{a}$ & $105 \mathrm{a}$ & $11.2 \mathrm{~b}$ & $0.6 \mathrm{ab}$ & $42 \mathrm{ab}$ & $3.1 \mathrm{ab}$ \\
\hline & BABA alternate & $1.2 \mathrm{a}$ & $80 \mathrm{a}$ & $11.2 \mathrm{~b}$ & $0.7 \mathrm{a}$ & $47 \mathrm{a}$ & $4.9 \mathrm{a}$ \\
\hline & Water & $1.4 \mathrm{a}$ & $80 \mathrm{a}$ & $15.4 \mathrm{a}$ & $0.5 \mathrm{~b}$ & $30.7 \mathrm{~b}$ & $1.8 \mathrm{~b}$ \\
\hline & & & $\mathrm{P}>\mathrm{F}$ & & & $\mathrm{P}>\mathrm{F}$ & \\
\hline MT & & 0.01 & 0.01 & 0.01 & 0.01 & 0.01 & 0.82 \\
\hline $\mathrm{T}$ & & 0.01 & 0.01 & 0.01 & 0.01 & 0.01 & 0.01 \\
\hline MT x T & & 0.01 & 0.01 & 0.53 & 0.23 & 0.44 & 0.58 \\
\hline
\end{tabular}

*Within each measurement time and variable, means followed by the same letter do not differ in Tukey's HSD test $(P=0.05)$. 

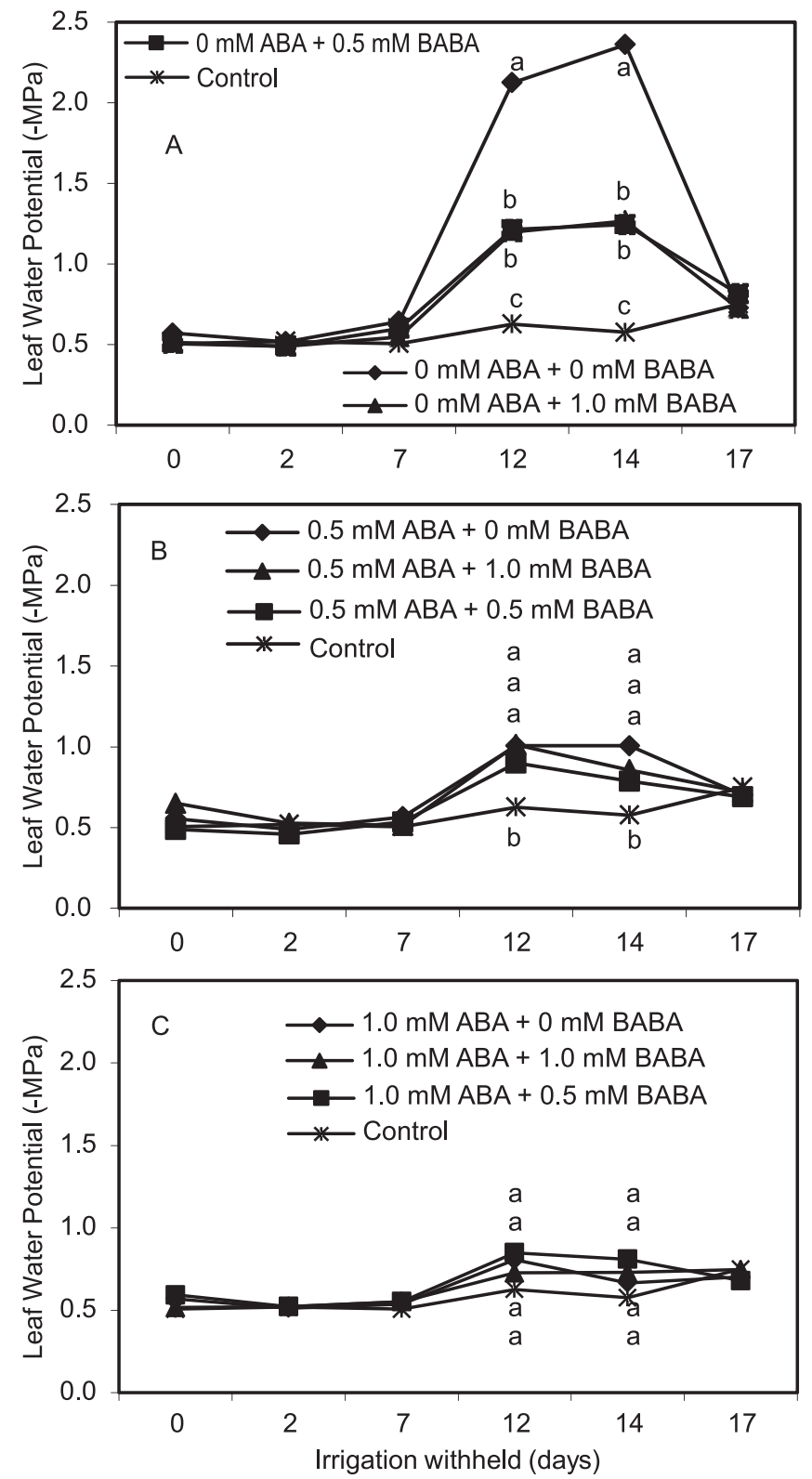

Fig. 1. Leaf water potential during drought of 'Royal Gala' apple trees treated with combinations of $\mathrm{BABA}$ and s-ABA followed by withholding water for 14 days. Top panel (A): $0 \mathrm{mM} \mathrm{s}-\mathrm{ABA}$ plus various concentrations of BABA. Middle panel (B): $0.5 \mathrm{mM} \mathrm{s}-\mathrm{ABA}$ plus various concentrations of BABA. Bottom panel (C): $1.0 \mathrm{mM}$ s-ABA plus various concentrations of BABA. Control indicates well-watered trees. Within each date and panel (s-ABA concentration) means with the same letter do not differ at $P=0.05$.

tree growth was 28,33 , and $15 \mathrm{~cm}$ for trees that were pre-treated with $0,0.5$, and $1.0 \mathrm{mM} \mathrm{s}-\mathrm{ABA}$, respectively (Fig. 2). Average tree growth was 28,37 , and $28 \mathrm{~cm}$ for trees that were pre-treated with $0,0.5$, and $1.0 \mathrm{mM}$ BABA, respectively. Pretreatment with BABA and s-ABA (1.0 mM each) resulted in substantial regrowth $(55 \mathrm{~cm})$.

Priming treatments reduced leaf ABA concentrations compared to dehydrated controls and ABA increased with increasing time without water (Table 3). The highest level of ABA was found in leaves of unwatered control trees. Neither s-ABA nor BABA increased foliar ABA levels after root drench. The highest ABA level was found in leaves of unwatered control trees after 12 and 14 days of dehydration. ABA levels were lower in leaves of trees after they were rewatered (day 17).
Table 3. Leaf ABA response to priming treatments with BABA and s$\mathrm{ABA}$ and to increasing time without water of 'Royal Gala' apple trees

\begin{tabular}{lccc}
\hline BABA & s-ABA & $\begin{array}{r}\text { Priming treatments* } \\
\text { Dehydration control }\end{array}$ & Watered control \\
\hline & \multicolumn{3}{c}{ (pmole ABA mg (p)af $)^{-2}$} \\
$0.68 \mathrm{ab}$ & $0.43 \mathrm{~b}$ & $1.02 \mathrm{a}$ & $0.47 \mathrm{~b}$
\end{tabular}

\begin{tabular}{|c|c|c|c|}
\hline \multicolumn{4}{|c|}{ Days without water } \\
\hline$\underline{0}$ & 12.00 & 14.00 & 17.00 \\
\hline \multicolumn{4}{|c|}{ (pmole $\mathrm{ABA} \mathrm{mg^{-2 }}$ leaf) } \\
\hline $0.60 \mathrm{a}$ & $0.99 \mathrm{a}$ & $0.94 \mathrm{a}$ & $0.08 \mathrm{~b}$ \\
\hline \multirow[t]{2}{*}{$\overline{\mathrm{P}>\mathrm{F}}$} & $\begin{array}{l}\text { Priming treatment } \\
(\mathrm{P})\end{array}$ & $\begin{array}{l}\text { Days without water } \\
\text { (DWW) }\end{array}$ & $\begin{array}{c}\text { Interaction } \\
(\mathrm{P} \times \mathrm{DWW})\end{array}$ \\
\hline & 0.086 & 0.003 & 0.616 \\
\hline
\end{tabular}

* Main effects are presented as no significant interaction was found between priming treatment and days without water. Within each row means followed by the same letter do not differ in Tukey's HSD test $(P=0.05)$.

\section{Discussion}

Plant water status was improved by priming with either BABA or s-ABA, but responses were inconsistent. In Experiment 1, pretreatment with BABA reduced early morning E, possibly as a strategy to reduce dehydration injury, but in Experiment 2 BABA was not as effective as S-ABA in delaying dehydrationinduced wilt of shoot tips. BABA-induced dehydration tolerance has been linked to ABA accumulation in Arabidopsis thaliana and reduction of the stomatal aperture size (Jakab et al., 2005). In our experiment, increased leaf ABA was found in the leaves of dehydrated control trees compared to primed trees (Table 3). During the second week without water in Experiment 3, both BABA- and s-ABA-treated trees had higher leaf $\psi_{\mathrm{w}}$ than controls but $\mathrm{E}$ and $\mathrm{g}_{\mathrm{s}}$ were similar for BABA, s-ABA, and untreated controls (Tables 1 and 2; Fig. 1). Foliar applications of the s-ABA formulation used in this experiment reduced evapotranspiration of Viburnum odoritissium (Craig Campell, personal communications 9/21/09). In the current study, root-applied s-ABA decreased $\mathrm{g}_{\mathrm{s}}$ after 7 days of drought (Table 2). Application timing, rate, and plant part receiving treatment can affect efficacy and these variables require further investigation. Combined applications of BABA and s-ABA provided the highest leaf $\psi_{w}$ compared to non-primed trees, but significant synergy between these bioregulators was not found at all s-ABA concentrations (Fig. 1; Table 2). However, at $1 \mathrm{mM} \mathrm{s-ABA}$ compared with control trees, there was nearly $80 \%$ more shoot growth after one month

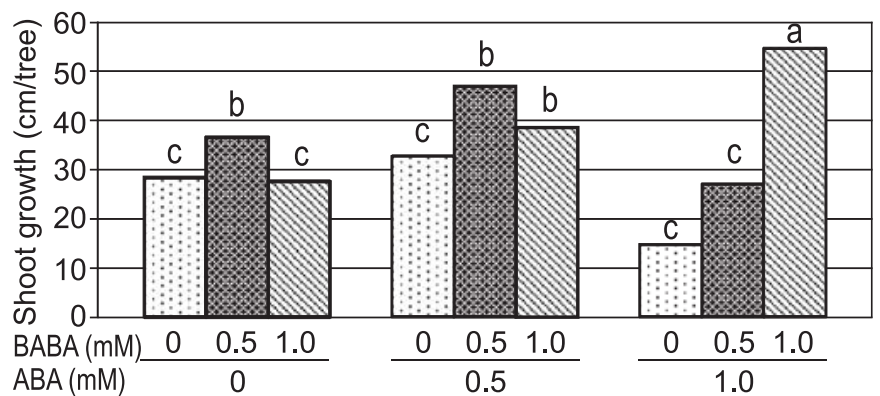

Fig. 2. Shoot growth of 'Royal Gala' apple trees treated with BABA and s-ABA, held for 14 days without water and then watered and grown for one month. Columns with the same lower case letter do not differ at the 0.05 level of significance. 
following rewatering after dehydration in trees that received combined BABA and s-ABA suggesting that there may be a concentration-related synergy. Growth following dehydration may be associated with primer effects on water-conducting tissue as noted by Macarisin et al. (2009).

Applications of BABA may confer plant protection against a wide range of biotic and abiotic stresses that may not directly affect gas exchange of the leaf (Jakab et al., 2005). In other work, BABAprimed plants accumulated callose and lignin and provided protection from pathogen attack, but also had increased tolerance to dehydration (Hamiduzzaman, 2005). Application of BABA can induce PAL (Newton et al., 1997) and PAL is associated with synthesis of lignin, resulting in narrow lumens of xylem elements. Narrower xylem elements can conserve water under dehydration conditions by decreasing hydraulic conductivity. Increased lignification also will reduce gas permeability and help prevent embolisms in xylem during dehydration (Hacke et al., 2000). Lignification may enable trees to achieve greater growth when rewatered following drought. Although s-ABA can induce PAL (Asselbergh et al., 2008), in the current experiment trees treated with $\mathrm{ABA}$ alone did not grow as much as $\mathrm{BABA}$-treated trees when watered after drought. It is possible that s-ABA improved survival of dehydration, but elevated ABA in shoot tips inhibited growth.

In these experiments, leaf senescence was more evident in sABA than BABA treated trees and, although growth resumed after drought, the amount of growth varied with concentration of the priming treatments (Fig. 2). Dehydration-control trees (no chemical priming) had higher leaf ABA than leaves of trees primed with $\mathrm{s}-\mathrm{ABA}$ and $\mathrm{BABA}$. It is possible that priming reduced dehydration stress and the endogenous levels of $\mathrm{ABA}$ compared to dehydration-control trees that had significantly lower water potential (Fig. 1). Both compounds provided dehydration protection to young apple trees but together they were not statistically superior to either compound alone. However, these results indicate that priming to reduce water-deficit stress in newly-planted fruit trees warrants further study.

\section{Acknowledgements}

We thank Craig Campbell, Valent BioSciences Corp. for the gift of s-ABA. We also thank Kevin Webb and Tony Rugh for technical assistance.

Disclaimer: Mention of trade names or commercial products in this publication is solely for the purpose of providing specific information and does not imply recommendation or endorsement by the U.S. Department of Agriculture. USDA is an equal opportunity provider and employer.

\section{References}

Amri, E. and A.R. Shahsavar, 2010. Response of lime seedlings (Citrus aurantifolia L.) to exogenous spermidine treatments under drought stress. Aust. J. Basic Appl. Sci., 4: 4483-4489.

Artlip, T.S. and M.E. Wisniewski, 2001. Induction of proteins in response to biotic and abiotic stresses. In: Handbook of Plant and Crop Physiology, M. Pessarakli, (ed.), Marcel Dekker, Inc., New York. pp.657-679.

Asare-Boamah, N.K., R.A. Hofstra, R.A. Fletcher and E.B. Dumbroff, 1986. Triadimefon protects bean plants from water stress through its effects on abscisic acid. Plant Cell Physiol., 27: 383-390.
Asselbergh, B., D. De Vleesschauwer and M. Höfte, 2008. Global switches and fine-tuning-ABA modulates plant pathogen defense. Molecular Plant-Microbe Interactions, 21: 709-719.

Blum, A. 1996. Crop responses to drought and the interpretation of adaptation. Plant Growth Regulation, 20: 135-148.

Bolar, J.P., V. Hanke, J.L. Norelli and H.S. Aldwinckle, 1998. An efficient method for rooting and acclimation of micropropagated apple cultivars. HortScience, 33: 1251-1252.

Boyer, J.S. 1982. Plant productivity and environment. Science, 218: 443-448.

Conrath U., J. Beckers and V. Flors, 2006. Priming: getting ready for battle. Molecular Plant-Microbe Interaction, 19: 1062-1071.

Conrath, U., C.M.J. Pieterse and B. Mauch-Mani, 2002. Priming in plantpathogen interactions. Trends Plant Science, 7: 210-216.

Creelman, R.A., H.S. Mason, R.J. Bensen, J.S. Boyer and J.E. Mullet, 1990. Water deficit and abscisic acid cause differential inhibition of shoot versus root growth in soybean seedling. Plant Physiol., 92: 205-214.

Funkhouser, E.A., J. Cairney, T.S. Artlip, S. Chang, M.A. Dias and R.J. Newton, 1994. Cellular and molecular responses to water-deficitstress in woody plants, In: Handbook of Plant and Crop Stress. M. Pessarakli (ed.), Marcel Dekker, Inc., New York. pp 347-362.

Guo, D., J. Liang and L. Li, 2009. Abscisic acid (ABA) inhibition of lateral root formation involves endogenous ABA biosynthesis in Arachis hypogaea L. Plant Growth Regul., 58: 173-179.

Hacke, U.G., J.S. Sperry and J. Pittermann, 2000. Drought experience and cavitation resistance in six shrubs from the Great Basin Utah. Basic and Applied Ecology, 1: 31-41.

Hamiduzzaman, M.M. 2005. $\beta$-aminobutyric acid-induced resistance in grapevine against downy mildew (Plasmopara viticola). Dissertation, University of Neuchâtel Institute of Botany, Laboratory of Biochemistry, $163 \mathrm{p}$.

Jakab, G., J. Ton, V. Flors, L. Zimmerli, J.P. Métraux and B. Mauch-Mani, 2005. Enhancing Arabidopsis salt and drought stress tolerance by chemical priming for its abscisic acid responses. Plant Physiology, 139: 267-274.

Ko, K., J.L. Norelli, J.P. Reynoird, H.S. Aldwinckle and S.K. Brown, 2002. T4 Lysozyme and attacin genes enhance resistance of transgenic 'galaxy' apple against Erwinia amylovora. J. Amer. Soc. Hort. Sci., 127: 515-519.

The Land Commodities Global Agriculture \& Farmland Investment Report, 2009. (Land Commodities Asset Management AG, Baar, Switzerland, 2009; www.landcommodities.com)

Macarisin, D., M.E. Wisniewski, C. Bassett and T.W. Thannhauser, 2009. Proteomic analysis of $\beta$-aminobutyric acid priming and abscisic acid - induction of drought resistance in crabapple (Malus pumila): effect on general metabolism, the phenylpropanoid pathway and cell wall enzymes. Plant Cell Environment, 32: 1612-1631.

Newton, A.C., S.K. Miller, G.D. Lyon and T. Reglinski, 1997. Resistance elicitors as crop protectants. Phytopathology, 87(Suppl.): S69 (Abst. ract)

Norelli, J.L., H.S. Aldwinckle and S.V. Beer, 1988. Virulence of Erwinia amylovora strains to Malus sp. Novole plants grown in vitro and in the greenhouse. Phytopathology, 78: 1292-1297.

Sauter, A., W.J. Davies and W. Hartung, 2001. The long-distance abscisic acid signal in the droughted plant: the fate of the hormone on its way from root to shoot. J. Exp. Bot., 52: 1991-1997.

Wang, S.Y. and G.L. Steffens, 1985. Effect of paclobutrazol on water stress-induced ethylene biosynthesis and polyamine accumulation in apple seedling leaves. Phytochemistry, 24: 2185-2190.

Wisniewski, M., C. Bassett, J. Norelli, D. Macarisin, T. Artlip, K. Gasic and S. Korban, 2008. Expressed sequence tag analysis of the response of apple (Malus $\mathrm{x}$ domestica) to low temperature and water deficit. Physiol. Plant., 133: 298-317. 
Yang, F., J. Hu, J. Li, X. Wu and Y. Qian, 2009. Chitosan enhances leaf membrane stability and antioxidant enzyme activities in apple seedlings under drought stress. Plant Growth Regul., 58: 131-136.

Zeevaart, J.A.D. and R.A. Creelman, 1988. Metabolism and physiology of abscisic acid. Annu. Rev. Plant Physiol. Plant Mol. Biol., 39: 439-473.

Zhang, J., W. Jia, J. Yan and A.M. Ismail, 2006. Role of ABA in integrating plant responses to drought and salt stresses. Field Crops Research, 97: 111-119.
Zhu, L., A. van de Peppel, X.. Li and M. Welander, 2004. Changes of leaf water potential and endogenous cytokinins in young apple trees treated with or without paclobutrazol under drought conditions. Scientia Horticulturae, 99: 133-141.

Received: August, 2011; Revised: October, 2011; Accepted: November, 2011 